\title{
Intravascular large B cell lymphoma limited in renal glomaruli: A case presented as nephrotic syndrome
}

\author{
Yingxue $\mathrm{Cao}^{1}$, Zhuxing Sun ${ }^{2}$, Liang Wang ${ }^{2}$, Jia Hua ${ }^{2}$, Shaojun Liu*1, Chuan-Ming Hao ${ }^{1}$ \\ ${ }^{1}$ Division of Nephrology, Huashan Hospital, Fudan University, Shanghai, China \\ ${ }^{2}$ Division of Nephrology, Wuxi People's Hospital, Wuxi, Jiangsu Province, China
}

Received: February 27, 2017

DOI: $10.5430 /$ crim.v4n2p45
Accepted: April 13, 2017

Online Published: April 25, 2017

\begin{abstract}
Intravascular large B cell lymphoma (IVLBCL) is a rare type of non-Hodgkin lymphoma, characterized by selective proliferation of B cells within the lumens of small vessels. We report a case of IVLBCL with the invaded B cells limited in the lumen of glomerular capillary loops. The patient presented with nephrotic syndrome. Histological examination of renal biopsy specimens showed infiltration of neoplastic cells limited in glomerular capillary loops, accompanied by diffuse foot process effacement only in those capillary loops with the infiltrative cells. Immunohistochemistry shows that the infiltrative cells were positive for bcl-2, bcl-6, CD20, MUM1 and ki-67, consistent with atypical cells deriving from B cells. Unfortunately, the patient refused the further treatment and died soon after the diagnosis.
\end{abstract}

Key Words: Intravascular large B cell lymphoma, Nephrotic syndrome, Glomerular limited, Renal biopsy

\section{INTRODUCTION}

Intravascular large B cell lymphoma (IVLBCL) is a rare type of non-Hodgkin lymphoma, characterized by selective proliferation of B cells within the lumens of small vessels, particular in capillaries, without involvement of the lymphoreticular organs. ${ }^{[1]}$ The most commonly affected organs are central nervous system, kidneys, lungs, and skin. ${ }^{[2,3]}$ The thromboembolic nature of the invaded B cells contributes to various clinical manifestations. The clinical manifestations are often non-specific, including fever, general fatigue, weight loss, anemia, and neurological alteration. The lack of specificity in clinical manifestation was a challenge for early diagnosis. ${ }^{[4]}$ In IVLBCL with kidney involvement, the invaded B cells could be in intraglomerular and/or in tubulointerstitium. ${ }^{[5]}$ Here we report a case of an intraglomerular type IVLBCL presented with nephrotic range of proteinuria.

\section{Case Presentation}

A 65-year-old man was admitted to our hospital because of foam urine and intermittent fever with mild weight loss on July 1, 2015. His past medical history showed COPD for more than 10 years, otherwise unremarkable. The patient had no hypertension and no diabetes. No HIV, HBV or $\mathrm{HCV}$ were reported. On the physical examination, the patient was found to be febrile $\left(\mathrm{T}=38.3^{\circ} \mathrm{C}\right)$ and had $2+$ pitting edema of the bilateral lower extremities. No skin lesion, hepatosplenomegaly, superficial lymphadenopathy or neurological abnormality were noted. Pertinent laboratory examination results were as follows: the leukocyte count was $6.76 \times 10^{9} / \mathrm{L}$ (reference interval: $4-10 \times 10^{9} / \mathrm{L}$ ), hemoglobin was $101 \mathrm{~g} / \mathrm{L}$ (reference interval: 105-160), erythrocyte count was $3.16 \times 10^{12} / \mathrm{L}$ (reference interval: $3.5-5.5 \times$ $10^{12} / \mathrm{L}$ ), platelet count was $69 \times 10^{9} / \mathrm{L}$ (reference interval:

*Correspondence: Shaojun Liu, MD; Email: liushaojun@fudan.edu.cn; Address: 12 Wulumuqi Road (middle), Division of Nephrology, Huashan Hospital, Fudan University, Shanghai 200040, China.

Published by Sciedu Press 
$80-300 \times 10^{9} / \mathrm{L}$ ), C-reactive protein $53 \mathrm{mg} / \mathrm{L}$ (reference interval: $0-8$ ), total blood protein $40.1 \mathrm{~g} / \mathrm{L}$ (reference interval: 55-80), serum albumin $20.2 \mathrm{~g} / \mathrm{L}$ (reference interval: $35-53$ ), serum creatinine $1.28 \mathrm{mg} / \mathrm{dl}$ (reference interval: 0.6-1.7), blood urea nitrogen $21.6 \mathrm{mg} / \mathrm{dl}$ (reference interval: 7-20), lactate dehydrogenase $903 \mathrm{U} / \mathrm{L}$ (reference interval: 109-245), erythrocyte sedimentation rate $55 \mathrm{~mm} / \mathrm{h}$ (reference interval: $\leq 15$ ), and ferritin 1,404.1 ng/ml (reference interval: 23.9 336.2). 24-hour urinary protein was $4.59 \mathrm{~g}$. Tumor markers: CA125 123. $6 \mathrm{U} / \mathrm{ml}$ (reference interval: < 35 in blood), others (AFP/CEA/CA199/PSA) were normal. Blood electrolytes were normal. Serology tests including ANA, ENA, ds-DNA antibody, ANCA, and anti-GBM antibody were normal. Complement $\mathrm{C} 3$ and $\mathrm{C} 4$ were in normal range. The serum IgA, IgG, IgM, kappa light chain and lambda light chain were all in normal range. Serum and urine immune fixation electrophoresis were negative. The blood culture was also negative.

Type-B ultrasound showed bilateral cervical subcutaneous low echo conglomeration, considered possible lymph nodes. Computed tomography (CT) scan of the chest revealed mild mediastinal enlarged lymph nodes and mild pneumonia. The bone marrow smear showed no abnormal cell population.

The patient was diagnosed as nephrotic syndrome and pneumonia, and was treated with glucocorticoid and antibiotics for 2 weeks. Twenty-four-hour urinary protein was significantly decreased from $4.59 \mathrm{~g}$ to $1.86 \mathrm{~g}$, but intermittent fever persisted. Renal biopsy was performed.
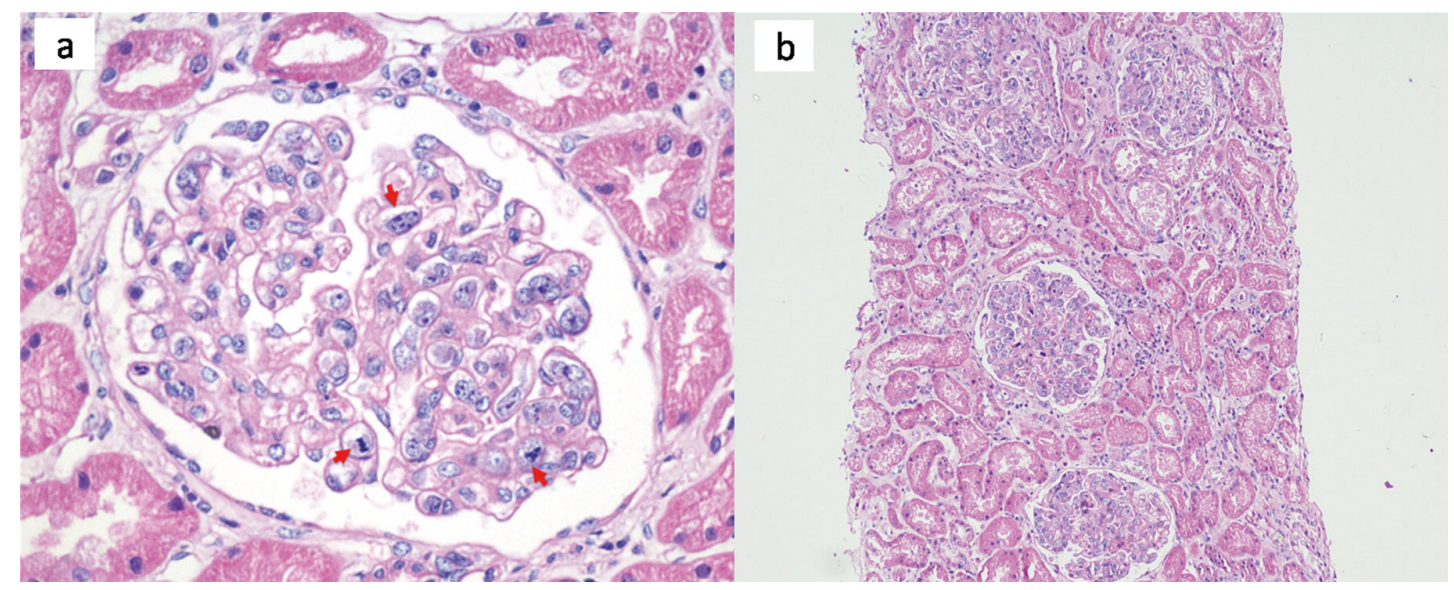

Figure 1. Atypical cells containing large, pale nuclei with rich nucleoli and mitotic figures (arrows) (a) (HE stain, $\times 400$ ); No invasive atypical cells can be seen in peritubular capillaries and tubules (b) (HE stain, $\times 100$ ).
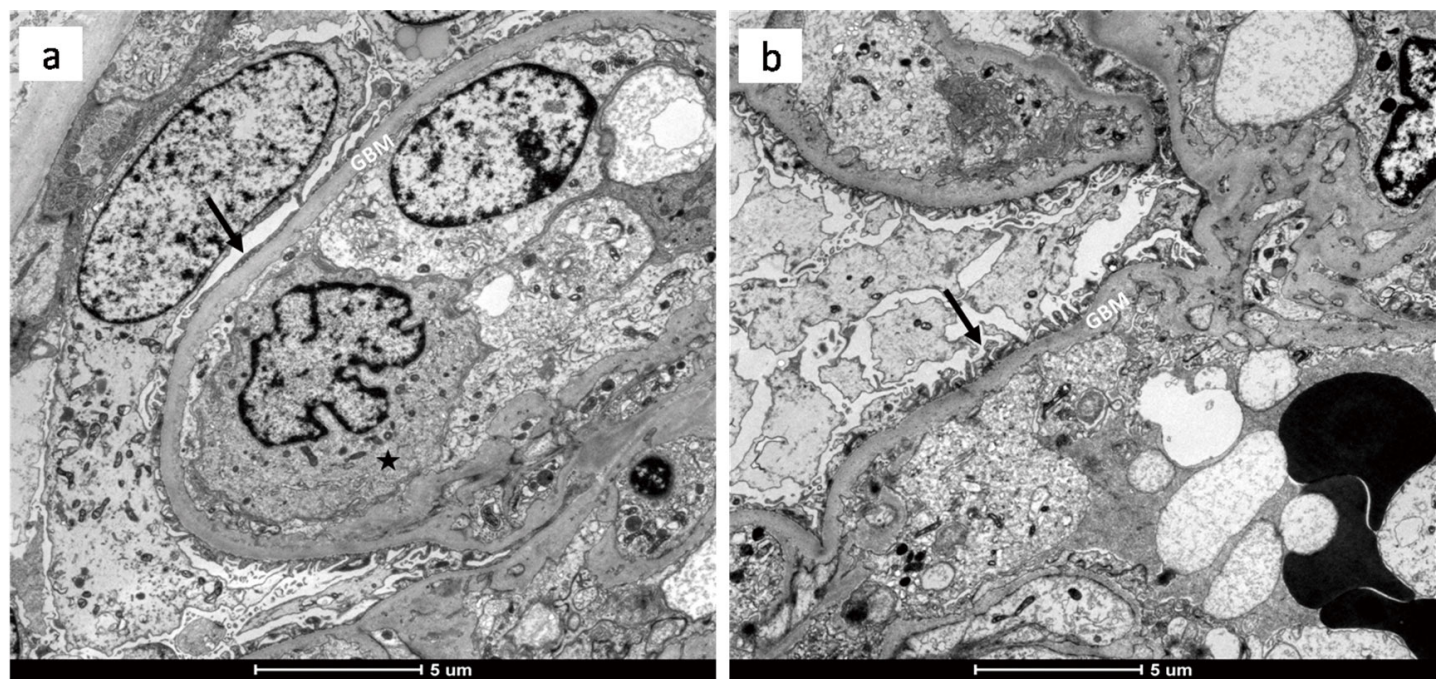

Figure 2. Electron microscopy of diffused foot process effacement (indicated by arrow in a) at the capillary segments with infiltrated atypical cells. Without the atypical cells the segments have no foot process effacement (indicated by arrow in b). 


\subsection{Renal biopsy}

Light microscopy of two cores biopsy tissue containing 31 glomeruli showed two glomeruli with global sclerosis. In the other glomeruli, capillary lumens were filled with large atypical cells. These atypical cells had large, pale nuclei with rich nucleoli. Mitotic figures were common in these cells (see Figure 1a). In contrast, no atypical cells were found in peritubular capillaries (see Figure 1b).

Immunofluorescence studies on frozen sections revealed no deposits of immunoglobulin, complement components and light chains.

Electron microscopy examination showed diffuse foot pro- cess effacement in the capillary segments with infiltrated atypical cells (see Figure 2a), but not in those capillary loops without the atypical cells (see Figure 2b). No dense deposits were seen under electron microscopy.

\subsection{Immunohistochemistry}

The atypical cells are positive for leukocyte common antigen bcl-2, bcl-6; B cell marker CD20 (see Figure 3a-b), MUM1, and cell proliferation marker Ki-67 (see Figure 3c). The T cell marker $\mathrm{CD} 3$ is positive in some cells, but the number is much less then that of the atypical cells (see Figure 3d). The pre B cell marker CD10 is negative (see Figure 3e).

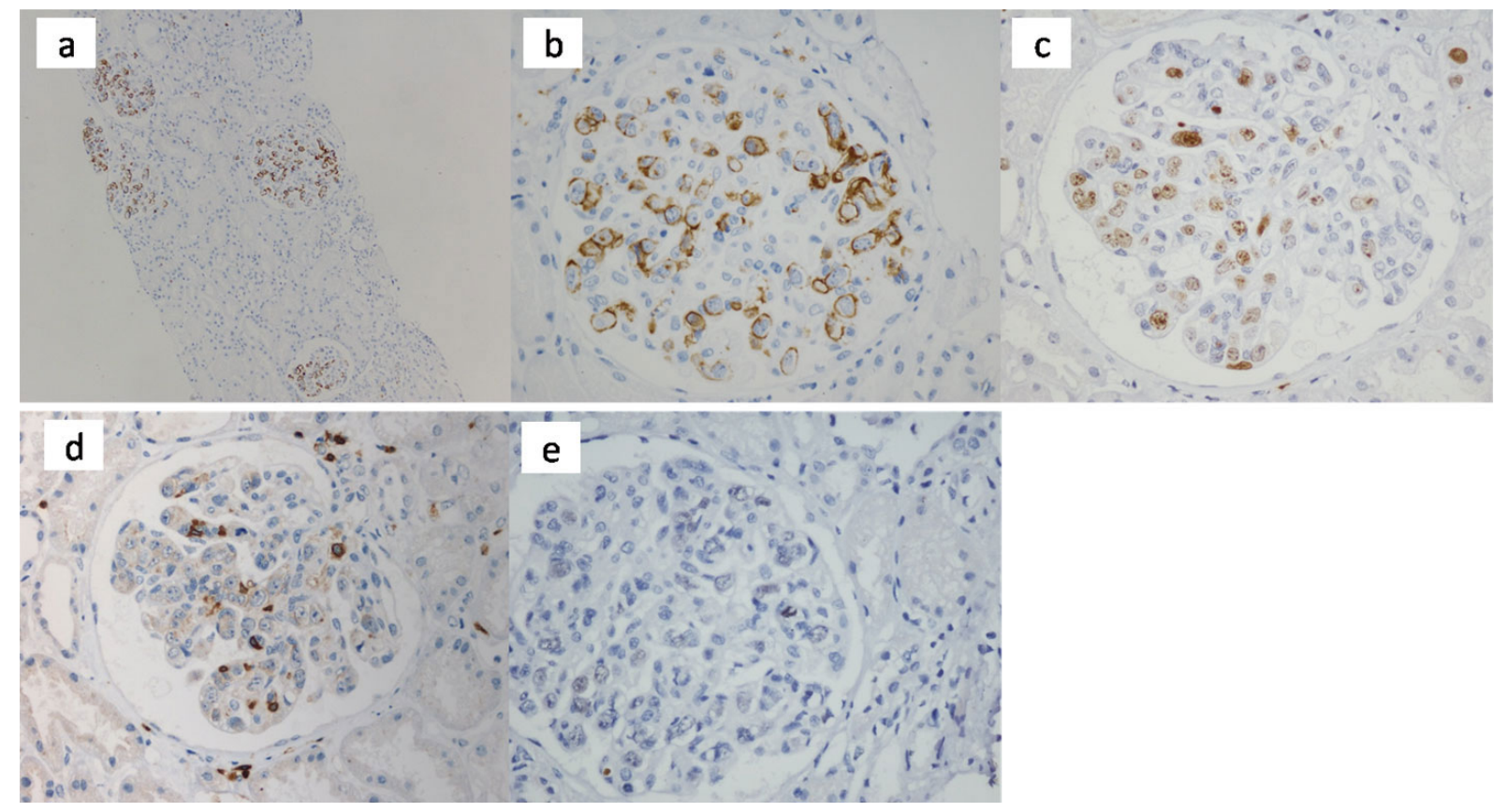

Figure 3. Immunohistochemistry on paraffin-embedded sections showing positive for CD20 $(\mathrm{a} \times 100, \mathrm{~b} \times 400)$ and Ki-67 $(c \times 400)$ in those large atypical cells. It is positive for CD3 (d). It is negative for CD10 (e).

The patient was diagnosed as IVLBCL. Combined with the obvious foot process effacement and no immune deposits, the patient also had a minimal change disease like change. Regretfully, the patient refused the further treatment and died soon.

\section{Discussion}

Intravascular large B cell lymphoma was first reported as angioendotheliomatosisproliferanssystemisata by Pfleger and Tappeiner in 1959, and was described as an invasive systemic malignant lymphoma with unconspicuous clinical presentations,aggressive behavior, and often rapidly fatal. ${ }^{[6,7]}$ According to a review by Ponzoni and Ferreri, the frequency of lymphoma cells disseminated in renal was $21 \%{ }^{[8]}$ There are only two reports presented with nephrotic syndrome. To Published by Sciedu Press the best of our knowledge, the only case of IVLBCL with the neoplastic cells limited in glomerular capillary loops was reported in 2013. ${ }^{[9]}$

In the present case, a 65-year-old man presented with foam urine and intermittent fever and high serum level of CRP, LDH and ferritin. The pathological morphology of renal biopsy exhibits significant hypercellularity restricted in the glomerular capillary loops, but not in the peritubular capillaries. Although the immunohistochemical staining of CD3 was positive in some cells,but the number was much less than the atypical cells, suggesting limited $\mathrm{T}$ cells infiltration. The positive staining of bcl-2, bcl-6, CD20, MUM1 and ki-67, and negative for CD10 by immunohistochemistry.

The mechanism by which the invaded atypical B cells are 
limited in the glomerular capillary loops is not clear. Although the peritubular capillaries are the continuation of glomerualr capillaries, the endothelium of glomerular capillary loops are unique. The glomerular endothelium has characteristic fenestrations. The renal microvascular endothelial cells especially in the glomeruli express a number of biologically active receptors that can bind to substances such as shiga toxins, which may cause thrombogenesis only in the glomeruli and lead to the post-diarrheal hemolytic uremic syndrome. Whether these characteristics of glomerular endothelial cells are also responsible for the restriction of the atypical B cells in the glomeruli as in the present case remains to be examined. Under electronic microscopy, diffuse foot processes were only found in glomerular capillary loops where the neoplastic cells were present, the foot pro- cesses were remained intact in uninvolved capillaries. These findings may suggest that certain product(s) released locally by the invasive lymphocytes contributes to the pathogenesis of MCD in this patient. The poor prognosis of the patient was another example that IVLBCL may cause rapidly death without effective treatment.

In summary, we report a case of IVLBCL presented withnephrotic syndrome. Pathological examination shows that the neoplastic cells were restricted only to glomerular capillary loops, and the presence of the invaded cells was closely associated with foot process effacement.

\section{CONFlicts OF INTEREST Disclosure}

The authors declare that there is no conflict of interest regarding the publication of this paper.

\section{REFERENCES}

[1] Wick MR. Intravascular lymphomatosis: clinicopathological features and differential diagnosis. Semin Diagn Pathol. 1991; 8: 91-101. PMid: 1871454

[2] Ponzoni M. Definition, diagnosis, and management of intravascular large B-cell lymphoma: proposals and perspectives from an international consensus meeting. J Clin Oncol. 2007; 25(21): 3168-73. PMid:17577023 https://doi.org/10.1200/JC0.2006.08.23 13

[3] Murase T. Intravascular large B-cell lymphoma (IVLBCL): aclinicopathologic study of 96 cases with special reference to the immunophenotypic heterogeneity of CD5. Blood. 2007; 109(2): 478-85. PMid:16985183 https://doi.org/10.1182/blood-2 006-01-021253

[4] Shimada K. Presentation and management of intravascular large B-cell lymphoma. Lancet Oncol. 2009; 10(9): 895-902. https:
//doi.org/10.1016/S1470-2045(09)70140-8

[5] Törnroth T. Lymphomas diagnosed by percutaneous kidney biopsy. Am J Kidney Dis. 2003; 42(5): 960-71. PMid:14582040 https: //doi.org/10.1016/j.ajkd.2003.08.004

[6] Pfleger L. On the recognition of systematized endotheliomatosis of the cutaneous blood vessels (reticuloendotheliosis?). Hautarzt. 1959; 10: 359-63. PMid: 14432547

[7] Zuckerman D. Intravascular lymphoma:the oncologist's "great imitator". Onocologist. 2006; 11(5): 496-502. PMid:16720850 https : //doi.org/10.1634/theoncologist.11-5-496

[8] Ponzoni M. Intravascular lymphoma: a neoplasm of 'homeless' lymphocytes? HematolOncol. 2006; 24(3): 105-12. https ://doi.or g/10.1002/hon. 776

[9] Jili Zhu. Mild proteinuria in a patient with glomerular-limited intravascular large B-cell lymphoma. 2013; 80(4): 286-92. 